\section{LESSON 32}

Tabulation 4

PAPER: A5 $(210 \times 148 \mathrm{~mm})$.

TARGET TIME: 10 minutes.

Turn up 14 single lines before starting: this will give you correct vertical display. Leave 2 blank lines after the title.

\section{Letter 11}

PAPER: A4.

MARGINS: Suitable.

\section{TODAY'S DATE}

TARGET TIME: 15 minutes.

Turn up 13 single-line spaces to allow for the printed heading.

\section{KINDS OF FISH}

$\begin{array}{llll}\text { Amberjack } & \text { Marlin } & \text { Shark } & \text { Trout } \\ \text { Barracuda } & \text { Pike } & \text { Sturgeon } & \text { Tunny } \\ \text { Bass } & \text { Sailfish } & \text { Swordfish } & \text { Turbot } \\ \text { Carp } & \text { Salmon } & \text { Tarpon } & \text { Whiting } \\ \text { Cod } & \text { Sawfish } & \text { Tope } & \text { Wrasse }\end{array}$

Ref. AP/SS

Self Service stores, 23, Ash sacet, wOLVERHAMPTON. WVZ IRA Dear sirs,

Thankyou for your letter of last monday in which you enquired about our range of car accessories. We have great pleacure in sending you our new catalogue and have arranged for our Wolverhampton Area Sales Representative to call and cee you. He will contact you in due cource to arrange a suitable time. (Paragraph) May we draw your atcention to the items listed on Page 46 of our catalogue. You will see that they are a rew style of fog lamps. We are prepared to offer these to you, as a new cuctomer, at 10 per cent above our normal crade discount provided that the lamps are ordered within the neoct two weeks. (Paragraph) we look forwand to heasing from you furcher and hope the meeting with our Representative results in trade to our mutual advantage. Yours foithfully, SUPER CAR ACCESSORY COMPANY

A. Peak

Sales Manager. Enc.
Display 3

PAPER: A5 $(148 \times 210 \mathrm{~mm})$.

TARGET TIME: 10 minutes.

Display with equal margins at top and bottom. There are 50 lines down this sheet: measure to find the middle using Method 1, Lesson 29. 